\title{
Debate: Políticas de ação afirmativa: inclusão no en- sino superior
}

José Carlos Miranda: agradeço o convite e a oportunidade de dialogar com pessoas interessadas em discutir o combate ao racismo e a luta por uma sociedade justa, onde todos sejam iguais, pois essa é uma discussão fundamental.

O debate sobre o racismo penetra cada aspecto de nossas vidas. Ao mesmo tempo, vivemos em um regime social que, do meu ponto de vista, é capitalista, portanto, de divisão em classes sociais. A sociedade está fundamentalmente dividida em duas classes: uma é apenas um grão de areia dentre os bilhóes de habitantes desse planeta e, a outra, os outros bilhóes que não têm nada a perder, somente os grilhóes da exploração. Nossa sociedade não está dividida entre homens, mulheres, crianças, idosos, negros, brancos e amarelos. Está dividida entre explorados e exploradores. A abolição da propriedade privada e dos grandes meios de produção é a única saída que possibilita uma sociedade realmente igualitária. Portanto, a luta de todo povo oprimido deve ter esse objetivo de quebrar as amarras da propriedade privada, que só sobrevive hoje a partir da superexploração da maioria dos habitantes desse planeta. Por mais que exista tecnologia e ela avance, esse é um sistema que, cada vez mais, só exclui.

Acredito que o debate de cotas raciais deva ser discutido a partir da perspectiva desse sistema desigual, desse modo de produção e organização da sociedade moderna. Cotas raciais não vão resolver o problema da ascensão dos descendentes de escravos - como eu e como a maioria nesse país - na universidade pública.
Elas não resolvem o problema, apenas jogam uma nuvem de fumaça para que não se enxergue a verdadeira raiz do problema. Devemos discutir a fundo para verdadeiramente encontrar a solução para as desigualdades. O verdadeiro problema hoje é esse sistema. Alguns podem dizer "só quando acabar esse sistema é que nós vamos dar um jeito no negócio?”. Não. Como socialista, creio e acredito que a única forma de chegarmos lá é lutar por medidas dentro do sistema em que vivemos, que apontam para lá, para uma sociedade sem explorados e exploradores, que é a divisão fundamental da sociedade baseada no regime da propriedade privada dos grandes meios de produçáo. $\mathrm{E}$ o socialismo, para mim, é um regime baseado na propriedade social dos grandes meios de produção controlados democraticamente pela maioria do povo. Como nós podemos lutar por essa sociedade? Diferenciando os trabalhadores e o povo, colocando na lei direitos e deveres diferentes de acordo com a tonalidade da cor de sua pele? Esse náo é o caminho da luta pela igualdade. É o caminho da divisão! A grande Revoluçáo Francesa, que varreu o conceito de que uns são mais diferentes do que outros, de que Deus baixou aqui com a varinha de condáo e classificou uns com sangue azul e outros não, foi uma enorme conquista da humanidade. Quando Danton, Robespierre, Saint-Just arrastaram as massas oprimidas e impuseram a igualdade jurídica dos cidadãos, fizeram um trabalho de gigantes, mas só foram até onde sua classe e condiçôes históricas permitiam. 
Toda esquerda na história moderna nasceu daí, da Comuna de Paris à Revolução Russa, todas verdadeiras revoluçôes até hoje beberam e estão impregnadas destas lutas. Conseguimos avançar porque a base do Manifesto Comunista, que para mim é um guia para ação, nasce da Carta dos Iguais; nasce, portanto, da luta por igualdade, liberdade e fraternidade.

Raça não existe mais. Existem seres humanos adaptados a seu habitat, ao lugar onde moram. Não existe raça disso ou daquilo. Raça foi inventada pelos racistas, com ajuda da Igreja Católica para justificar algo injustificável. O que foi a escravidão? Um genocídio, que arrancou milhōes de homens, mulheres e crianças do continente africano para trabalharem como escravos nas Américas. Existe o racismo? Existe e eu não aceito que digam o contrário, porque toda vez, mesmo com 40 anos de idade, que eu sou parado pela polícia, eu sei o que é o racismo. Ao observarmos a televisão, sabemos o que é o racismo. Ao observarmos as estatísticas também vemos o que é o racismo. Como mudar isso?

Primeiramente, gostaria de passar algumas informaçôes. Não me oponho a cotas sociais (reserva de vagas para alunos oriundos de escolas públicas e baixa renda), mas sei, e tenho certeza de que todos sabem, que não resolveráo o problema. É preciso aumentar radicalmente o número de vagas até acabar com o vestibular; a universidade pública brasileira é elitista. $\mathrm{O}$ que existe no Brasil de mais profundo é o enorme abismo entre as classes sociais. Posso até ser a favor de açóes afirmativas, mas as palavras são tão fraudadas ultimamente! Quando digo ação afirmativa não estou querendo dizer sobre a palavra, mas sobre o que há de concreto nela. Desde 1972, no país mais rico e poderoso do mundo, essas políticas, as chamadas açôes afirmativas, inventadas pela elite racista norteamericana, são aplicadas nos Estados Unidos. Trinta anos depois, qual é a situação dos negros nos Estados Unidos? Não mudou substancialmente. Os negros que ascenderam pela política de ação afirmativa viraram defensores do sistema e perpetuam as desigualdades. Vejam a contradição do ascenso de Condoleezza Rice (secretária de Estado norte-americana) e o crescimento da distância dos mais pobres para os mais ricos nos EUA. Vejam as vítimas do furacáo Katrina em 2004. O problema dos negros foi resolvido? Alguns podem dizer que a situação no Brasil é terrível, porque você entra na sala de aula e não vê um só negro. Vocês acham que o negro se sente bem em entrar em lugar no qual é o único negro? Claro que não, mas, como combater isso? Será que criar uma elite conservadora, como nos EUA, burguesa negra resolve o problema do povo negro? Cota e Estatuto não resolvem o problema e ainda opóem os pobres, brancos e negros. Porque o Brasil não é os Estados Unidos, onde se inventou o termo Afroamerican. Sabem por quê? Porque a ligação dos norte-americanos com a África sumiu, eles não possuem sincretismo cultural, religioso ou nacional; o sincretismo é indesejável.

Para concluir, queria dizer aos meus companheiros de luta socialista, que se baseiam no marxismo: cuidado com a armadilha de que é possível dar face humana ao capitalismo. Eu li a declaração da maioria dos partidos de esquerda, corrente de esquerda, tendência de esquerda, agrupamento de esquerda. Vi também a declaração da direita da ONU, do FMI e do Banco Mundial que são favoráveis à aplicação de cotas e à divisão dos países em etnias. Atenção para não cairmos na ilusão de que nós estamos dando uma força para aqueles que foram mais massacrados, que estão na base da pirâmide social. A única "cota" e a única "reparação" que pode interessar aos socialistas e ao povo oprimido é: trabalho, serviço público de qualidade e mais geração de empregos para todos - vagas nas universidades para todos! Somos todos irmãos trabalhadores, brancos, negros, índios, 
mestiços, o povo oprimido desse país. Cotas só vão jogar nuvens de fumaça nessa discussão.

Frei David dos Santos: Para nós, da Educafro, as cotas colocam a questáo da coexistência das etnias como um desafio a ser trabalhado. $\mathrm{O}$ direito de ingressar em uma universidade pública não pode ser privilégio de uma etnia. Coexistência é também dividir as oportunidades. Nossa visão é a de que a questão do negro extrapola qualquer visão ideológica, política e partidária, pois queremos ver os direitos dos negros sendo debatidos em todos os partidos políticos de esquerda, de direita e de centro. Por quê? Porque entendemos que, trabalhando com o tema da coexistência, "Saber coexistir com o diferente", estamos deixando bem evidenciado que queremos igualdade. A coexistência é um movimento mundial, e o povo judeu, uma das grandes vítimas da intolerância, tem muito a nos ajudar neste processo.

O debate das cotas e das açóes afirmativas foi colocado em um contexto de poucas vagas nas universidades públicas e, por outro lado, da grande necessidade por parte da comunidade negra de ter seus direitos reconhecidos. Os partidos que estão no poder náo têm este tema como prioridade e nós não queremos esperar propostas e promessas para serem realizadas daqui a trinta ou quarenta anos. Queremos, por exemplo, participação já do pouco que se tem de vagas nas universidades. Já assistimos a este filme de se esperar o bolo crescer para depois dividi-lo. No Brasil, apesar de todo o movimento socialista, as universidades são "propriedades" de um segmento étnico e nós entendemos que isso não é justo, isso não é ético. A coexistência está ancorada na idéia da participação de todos. Os que são partidários da coexistência devem advogar os direitos iguais. Não queremos esperar o bolo crescer para repartir, pois essa história é bem antiga...

A atitude de coexistência exige de todos nós muita reflexão, atitude e coragem, além da adoção de políticas de ação afirmativa para vivermos em harmonia, como irmãos. Nós, que acreditamos na coexistência, temos uma missão: fazer florescer o direito e a justiça como linguagem, atitude e ação da humanidade. Atitude de amor ao pai da humanidade e a todas as pessoas. Entendemos que é decisivo rever o acesso à educação pública no Brasil. $\mathrm{O}$ trabalho da Educafro tem como foco e estratégia a inclusão no Ensino Superior. Pessoas que ingressaram no projeto conseguiram entrar em universidades e passaram a ser multiplicadoras. Pensaram nos outros e, com esta atitude, investiram na coexistência.

Um censo étnico realizado aqui dentro da USP revelou que 79,54\% dos alunos da USP são eurodescendentes; $8,64 \%$ são pardos e apenas $1,03 \%$ são negros, portanto, o número de afrodescendentes é de apenas $9,67 \%$. Os afrodescendentes no Brasil somam 45,6\%, segundo as estatísticas do IBGE. A pergunta é: o índice de presença de afros na USP é justo? É justo que a USP continue deixando esse grande instrumento de mudança, que é o ingresso nas universidades, somente à disposição dos eurodescendentes? Por que ela não quer criticar e rever estrutura excludente? A culpa é da estrutura exageradamente elitista e burguesa sobre a qual está montado o Ensino Superior brasileiro, que se fecha conscientemente para os pobres e para os negros. O Estado que aprova o vestibular excludente da USP é o mesmo Estado que aprova e fiscaliza a qualidade do Ensino Médio da rede pública e não condena essa realidade de exclusão. $O$ Estado sabe muito bem qual é o conteúdo dado no Ensino Médio, mesmo assim, permite que a USP coloque no seu vestibular aquilo que não é dado no Ensino Médio público. O Estado e a USP, que pertence ao Estado, ludibriam o povo. $\mathrm{O}$ que queremos, precisamente, dizer? Vejamos esta comparação: imaginem que haverá uma corrida com importantes prêmios. Temos do 
lado direito, cem pessoas e, do lado esquerdo, outras cem. Para aquelas cem do lado direito, você dá bons treinadores, boa alimentação, boa educação física e assistência médica. Para as do lado esquerdo, você não dá nada. Deixa-as sem treinador, sem alimentaçáo e sem assistência médica. De qual dos dois grupos deverá sair os vencedores? Ninguém tem dúvida. Assim é o vestibular da USP. É um jogo de cartas marcadas onde, antecipadamente, já estáo definidos os perdedores e os ganhadores.

Com a implantação da ação afirmativa, procuramos aumentar a esperança dos pobres por inclusão. Isto é um parâmetro para se dizer que se valoriza a coexistência. Queremos inclusão para pobres e negros já. As cotas têm que garantir que $50 \%$ das vagas sejam destinadas aos alunos de Ensino Público e aos excluídos. É um aceno à coexistência, lembrando que para nós esta é só uma meta inicial, porque a nossa grande meta é garantir que o mesmo número de alunos da rede pública que terminam o Ensino Médio entre na universidade.

Neste sentido, as cotas são um profundo questionamento à meritocracia, bem como um instrumento de reparação histórica aos negros e negras. $\mathrm{O}$ ingresso de estudantes negros e pobres por meio das cotas, segundo a UnB, UERJ e outras universidades que aderiram a essa política, só melhorou a qualidade acadêmica das universidades públicas. Podemos ver esses resultados em várias manchetes de jornais, editadas ao longo de 2005 e 2006, que comprovaram que a excelência na qualidade do ensino ampliou-se na medida em que se investiu na diversidade étnica e socioeconômica em todos os cursos e turnos. As cotas na UERJ são um exemplo de sucesso: após um ano, 48,9\% dos estudantes que entraram via programa de cotas foram aprovados em todas as disciplinas, contra os $47 \%$ da classe média, que ingressou sem o auxílio das cotas. Portanto, já está provado na UERJ que a população negra ingressante naquela universidade, com seu esforço e garra, elevou a qualidade do Ensino Superior.

De acordo com dados do vestibular da USP de 2006, nenhum negro foi aprovado no vestibular para 42 faculdades da USP, o que significa uma exclusão em alto grau. Em três faculdades da USP, $0 \%$ de alunos da cor parda foi aprovado. Para vergonha do nosso Brasil, esses dados foram divulgados em 48 países através da BBC de Londres. Ou seja, a USP está sendo apresentada, em várias partes do mundo, como grande instrumento de exclusão de pobres e negros... Por que professores, alunos e direção da USP não estão com garra para mudar esta realidade?

Queremos justiça! Como os defensores da coexistência deverão agir para implantar as reparaçóes que o mundo precisa empreender para que haja a verdadeira justiça entre as etnias? Nós, afro-brasileiros, queremos reparação pelos 388 anos de escravidão e outros anos de exclusão do povo afro-brasileiro. Aqueles que são contrários a essa política estão preocupados com o fato de que o crescimento da consciência negra irá resultar em novos conflitos. Eles dizem que nós, negros conscientes, com o nosso debate e conscientização, iremos aumentar o conflito. Discordamos. Nós acreditamos num Brasil em que nossos irmãos brancos entendam que a justiça e a paz se abraçarão quando reconhecerem que precisamos partilhar mais. Frente ao grande número de empobrecidos, afirmamos que toda riqueza no Brasil tem sua origem na exploração do irmão negro, indígena etc. Temos que agir já, para impedir que a exclusão cresça ainda mais. Somos contra a ascensão do ódio racial em nosso país, provocado pelo fechamento do coração e ausência de partilha de quem acumulou. $\mathrm{O}$ que vai criar o ódio no país não são as cotas. Pelo contrário, $\mathrm{o}$ que poderá criar o ódio racial é a ausência de partilha e o acúmulo de poder, de saber etc. pelo sistema em que um só segmento étnico domina tudo. 
Yvonne Maggie: Em primeiro lugar, quero agradecer o convite. Eu tinha decidido náo participar mais desses debates, mas resolvi aceitar participar do debate porque o convite partia de estudantes, sobretudo da USP, o que me fez relevar a decisão anterior. $\mathrm{O}$ que nos coloca juntos nessa mesa, apesar de nossas diferenças políticas, de posição de classe, de posição religiosa, é o fato de todos nós acreditarmos que deve haver uma mudança no Brasil por maior justiça e eqüidade. Esse é o princípio que faz com que esse debate exista.

Eu quero começar dizendo que nós só podemos debater isso porque há alguma coisa que nos une nessa mesa e nessa platéia: a idéia e a vontade de que o Brasil seja um país mais justo e equânime. No entanto, divergimos em pontos essenciais. O primeiro deles é como conseguir essa maior eqüidade e justiça? Os dilemas enfrentados pela universidade, em minha opinião, não serão resolvidos a partir de políticas cujo foco é a "raça". A própria idéia de uma política baseada na "raça" já me deixa assustada, porque eu aprendi com a antropologia que a nossa tarefa é buscar demonstrar a universalidade do ser humano, buscar a universalidade na diferença. Foi nessa escola que eu me formei.

Até 2001, ou pelo menos até 1988, tínhamos uma legislação a-racial, ou seja, o Brasil não se tinha definido, em sua legislação, nem a favor, nem contra; não havia nomeação de "raça". Enquanto debatemos aqui a nossa constituição de 1890, que é uma constituição extremamente moderna, o mundo lá fora, os Estados Unidos e a África do Sul, dividiam suas sociedades em dois grupos raciais e definiam diferentes direitos para cada um. Nos Estados Unidos, por exemplo, a lei de Jim Crow $^{1}$ começou na década de

1. As leis de Jim Crow, instituídas em âmbito local e estadual nos Estados Unidos em 1876, decretaram que os locais públicos, tais como escolas públicas, trens e ônibus, tivessem instalaçóes separadas para brancos e negros. Essas leis vigoraram até 1965 [nota do editor].
1940. Na África do Sul, as leis do apartheid também foram estabelecidas nessa época. São leis sinistras que dividiram o povo em "raças" distintas, com direitos distintos. São leis que propiciaram a violência sem paralelo na história, com monstruosidades inimagináveis do ponto de vista do respeito à humanidade. Enquanto isso, no Brasil, optávamos por uma legislação a-racial e estávamos regidos por um estatuto jurídico universalista e republicano. Isso não quer dizer que aqui não houvesse desigualdade, racismo e violência. No entanto, quando a lei é universal, há um repúdio a qualquer ato que desrespeite esta universalidade. Por isso, o racismo no Brasil é reprimido culturalmente. $\mathrm{O}$ racismo é crime punido na forma da lei.

$\mathrm{O}$ que significou a mudança na legislação brasileira a partir de um determinado momento e essa tomada de posição em relação ao universalismo e ao a-racialismo? Em 2001, o Brasil participou da Conferência Mundial de Combate ao Racismo, à Xenofobia e às Intolerâncias Correlatas, organizada pela ONU em Durban, na África no Sul. Foi na preparação desse evento que o governo brasileiro, apoiado pelo IPEA [Instituto de Pesquisas Econômicas Aplicadas], começou a elaborar um modelo que veio a ser o modelo preconizado pelo governo de Fernando Henrique Cardoso (PSDB). Nessa conferência de Durban, a delegação brasileira propôs cotas raciais para o Ensino Superior, proposta esta que foi sancionada pelo governo Fernando Henrique Cardoso. Paralelamente, como se fosse um rastilho de pólvora, foram criadas leis estaduais e federais que propuseram políticas de ação afirmativa com base na "raça". O governo Fernando Henrique Cardoso propôs e determinou, por decreto, legalmente, cotas raciais no serviço público federal. A UERJ, por seu turno, foi obrigada a adotar cotas raciais a partir de uma legislação votada por aclamação na Assembléia Legislativa do Rio de Janeiro, e assim foi em vários outros Estados. Muitos 
Conselhos Universitários votaram também suas leis de cotas.

Quando o governo Luiz Inácio Lula da Silva assumiu, esta ênfase nas ações afirmativas se aprofundou. $\mathrm{O}$ governo Lula implantou a Secretaria Especial de Promoção de Políticas da Igualdade Racial (SEPPIR) e várias outras medidas no sentido de implantar açóes afirmativas. No PROUNI [Programa Universidade para Todos] e no Fundo de Financiamento ao Estudante do Ensino Superior (FIES) foi incluído o critério racial para a distribuição do direito. Essa história culminou em dois projetos de lei que já vinham sendo discutidos em círculos restritos da burocracia do Estado e em alguns movimentos sociais há algum tempo, mas náo estavam sendo debatidos pela sociedade como um todo. Os dois projetos, o projeto de Lei de Cotas (PL 73/1999) e do Estatuto da Igualdade Racial (PL 3.198/2000) atualmente estão tramitando no Congresso Nacional.

Esse é um breve histórico da mudança de uma perspectiva de Estado com estatuto legal a-racial para outra perspectiva, cujo fundamento está na distribuição de direitos com base na "raça". Essa idéia baseia-se no argumento central de que a sociedade já está dividida, já tem "raças", portanto, é preciso criar uma lei de proteção àqueles que são mais desvalidos, ou seja, os de "raça" negra.

Essa idéia surgiu dos movimentos sociais, mas foi encampada por certa elite brasileira, inclusive por parcelas significativas de professores universitários. Adotar "raça" para distribuição de direitos e como política de estado significa uma mudança radical nas nossas vidas, no nosso cotidiano, e não só dos negros, mas de todos os brasileiros brancos, negros, mestiços de toda a sorte, ricos e pobres. O Brasil terá agora uma legislação baseada na idéia de que existem "raças", mesmo que elas sejam sociais ou socialmente construídas. Segundo essa nova perspectiva, as "raças" existem e o país já é segregado de fato. Por isso, não basta o combate ao racismo e às desigualdades apenas pela legislaçáo antiracista vigente no Brasil desde a constituição de 1890 e mais especificamente desde a lei Afonso Arinos na década de 1950. A idéia vigente até entấo era que raça e racismo tinham que ser banidos da sociedade humana, pois naqueles anos 50 , quando essa legislaçáo foi criada, havia todo um movimento internacional de combate ao racismo. Era um movimento que unia todos em torno da idéia de que era preciso que nos pensássemos como seres humanos universais. No novo estatuto que se quer criar no Brasil, essa perspectiva muda radicalmente porque se quer combater o racismo criando uma legislaçáo que paradoxalmente institui a idéia de "raça".

Essa mudança radical na maneira de estruturar a naçấo brasileira e de conceber direitos diferenciais a partir dessa idéia de "raça" é uma mudança qualitativa no nosso sistema de pensar a nação. A nação, agora, não será mais pensada como composta de cidadãos que têm direitos iguais. $\mathrm{Na}$ nossa nação, agora, sobretudo se essas legislaçóes de cunho nacional e estatal forem aprovadas, o Estado estará legislando em nome da "raça". Teremos um Estado que optou por dividir a sociedade brasileira legalmente. Não lutaremos mais por uma sociedade universal e cosmopolita. A sociedade será pensada a partir da idéia de "diversidade" na qual estas diferenças implicarão em separação determinada em lei. O chamado Estatuto da Igualdade Racial, que todos devem ler, é um documento impressionante, como disse José Carlos Miranda, pois coloca em questão não só a universalidade do ser humano, como obriga todo cidadáo em todos os momentos de sua vida a se definir racialmente "sou negro, branco ou amarelo". Obriga também que nosso documento de identidade declare a nossa identidade étnica ou racial, como está dizendo Frei David. O Brasil, que era um país que se pensava culturalmente como um país de brasileiros, passa 
agora legalmente a ser definido como um país de duas etnias: os negros e os brancos. Ou seja, a partir de agora, nós vamos ter que dizer - legalmente - a qual delas pertencemos. Toda a vez que o Estado decidiu impor uma identidade a cada cidadão, coisas muito tristes e danosas aconteceram no mundo. Basta olhar para o Oriente Médio, por exemplo, ou para a Europa do Leste ou para a África.

Diante desta tentativa de mudança radical de nosso estatuto jurídico, eu me posicionei contra as ações afirmativas. Não porque eu esteja defendendo privilégios na universidade. A universidade pública, sobretudo as universidades federais, são as instituiçóes mais retrógradas desse país. Qual é a grande mudança que foi feita nessa universidade desde a reforma de 1969? Há muito tempo a universidade não repensa o seu caminho. No entanto, a forma que nós escolhemos para mudar a universidade e mudar o Brasil talvez seja um caminho sem volta. A partir do momento em que o Estado legisla, define legalmente e impóe aos cidadãos que optem por tal ou qual etnia, por tal ou qual identidade, o Estado estará criando as condiçóes para a luta fratricida. A história recente do mundo nos ensina esta lição, basta olhar para o mundo com olhos de ver. E eu vou me posicionar contra isso o quanto eu puder. Mesmo que isso me imponha tantos dissabores, como tem acontecido.

Dojival Vieira: Eu queria, em primeiro lugar, cumprimentar todos que participam dessa mesa. Como vocês verão, respeito a Profa. Maggie, mas dela discordo radicalmente.

Em primeiro lugar, é importante que a gente entre na história desse país, que não pode ser ignorada e tem que ser resgatada! O Brasil foi o último país do mundo a abolir a escravidão. $\mathrm{E}$ foi o país que mais seqüestrou homens e mulheres negros escravizados da África, durante mais de 350 anos. E a abolição que se deu nesse país ocorreu apenas no plano formal, jamais no plano material. Aqui, a escravidão se implanta objetivamente em 1534, e atravessa o ciclo da cana de açúcar, o ciclo do ouro, o ciclo do café. Náo é possível pensar o Brasil sem essa força de trabalho escravizada durante mais de três séculos e meio. E essa força de trabalho "ganha de presente" a liberdade, o que é uma falsidade histórica. A liberdade jamais foi um presente. A abolição que se fez aqui foi uma abolição que não representou a inclusão, a inserção da população negra, majoritária desde sempre no país, nos direitos básicos da cidadania. Ao contrário, o dia 13 de maio é o mais longo da história desse país, porque continua sendo vivido até hoje.

Não tenho nenhuma preocupação com que cada pessoa assuma sua condição étnica. Ao contrário, muito ao contrário. Aliás, isso já acontece, ninguém precisa se alarmar com o Estatuto da Igualdade Racial, nem com as políticas de ação afirmativa. O censo do IBGE, por exemplo, já pergunta para cada um, qual é sua cor ou raça. O IBGE estabelece cinco classificaçóes: preto, pardo, amarelo, indígena e branco. Detalhe: o critério é auto-declaratório! Ninguém é obrigado a se declarar negro sem sê-lo ou se declarar branco sem se considerar branco. O critério do IBGE é auto-declaratório e as pessoas se afirmam. Ignorar este aspecto é ignorar, professora Yvonne Maggie e demais companheiros da mesa, que esta aboliçáo que foi feita aqui, além de ter se restringido ao plano formal, foi seguida de uma política de branqueamento que existiu e é mantida no período pós-aboliçáo. Uma política de branqueamento que começou com a queima dos arquivos da escravidão por Rui Barbosa, então ministro da Fazenda, em 1891.

E começou a virar realidade com a vinda ao país em trinta anos, de quase a mesma quantidade de negros e negras que foram escravizados na África durante 350 anos. Vejam que os historiadores dizem que, durante cerca de 
$246 \mid$ Debate

350 anos, cerca de cinco milhôes de africanos foram trazidos ao Brasil como mão de obra escrava. Durante trinta anos, de 1890 até 1920 , o Estado brasileiro patrocinou a vinda de 4,5 milhóes de imigrantes, especialmente alemães e italianos. Era o pensamento dos racistas de plantão de que esse país não conseguiria se desenvolver se não se branqueasse. Era necessário, desse modo, deixar os negros à margem $\mathrm{e}$ sem direitos, e trazer milhôes e milhóes de imigrantes italianos e alemães por conta de uma política implementada pelo Estado brasileiro! Os imigrantes que vieram para cá vieram em situação absolutamente diferenciada daquela em que foram arrastados milhóes de negros e negras do continente africano. Com a ajuda do Estado, vieram pra cá com a garantia de trabalho, de moradia e puderam escolher para onde queriam ir.

Professora Yvonne Maggie falava sobre a Constituição brasileira. A Constituição Imperial se estruturou com a idéia de que todos eram iguais perante a lei, mas, no entanto, aqui havia a escravidão. A Constituição de 1891, já sob a República, se estruturou sobre os escombros do regime de escravidão, porque os negros não tinham casa, não tinham trabalho e seus filhos, durante séculos, foram proibidos de freqüentar escolas. Eu não sei se vocês sabem, mas havia legislações em várias províncias do país que proibiam negros e filhos de negros a freqüentarem a escola. Esses negros ficaram mantidos à margem, e para onde eles foram? Eles ocuparam as franjas, os morros, e passaram a sobreviver de bicos, e esta é a situação em que nos encontramos até hoje. Houve alguma mudança, houve avanço? Houve, mas, essencialmente, a situação é a mesma. E foi essa mesma Constituição de 1891 que estabeleceu a medida para materializar a política de branqueamento, sob a égide e a idéia do racismo científico, segundo o qual esse país não se desenvolveria sem se branquear, como já disse.
Do mesmo modo, a Constituição de 1934 falava em eugenia. Na Constituição de 1946, por sua vez, a Constituição da redemocratização do país após a ditadura do Estado Novo, pode-se ler o decreto 7.967, no qual a teoria do branqueamento ganhava um dispositivo que instituía que "os imigrantes seriam admitidos em conformidade com a necessidade de preservar e desenvolver o Brasil na composiçáo de sua ascendência européia”.

Está escrito! Então, que Constituição a-racial é essa, professora Yvonne Maggie? Quando se propóe que cada um resgate sua identidade, assuma sua identidade? Porque nós todos sabemos que um povo sem identidade não tem auto-estima. Aliás, esta é a razão pela qual a nossa auto-estima anda no chão, nós não nos orgulhamos da nossa identidade. Não haverá guerras fratricidas aqui não, professora Yvonne Maggie. Ao contrário, haverá um país em contato com a sua identidade, haverá um país que se encontra na diversidade da sua identidade. O que não é correto, o que não está certo é a idéia de que esse país possa se valorizar a partir de sua ascendência européia, pois, de fato, ele não é europeu. Ele é branco, ele é negro, e ele é indígena, e é exatamente esse conjunto de etnias, de povos, de naçóes, de culturas que faz com que o Brasil seja o Brasil.

Esse Brasil branco, europeu, que se mira na Europa e que durante séculos pretendeu se fazer à imagem e semelhança da Europa é o Brasil de uma elite racista que não suporta a diferença, e que fez com que, hoje, nós tenhamos uma situação e um quadro de um verdadeiro apartheid de natureza racial, que náo pode mais ser negado, nem escondido. Quando falamos das cotas e das açóes afirmativas, nós estamos falando de poder, pois quem sabe, pode, e sabe o quanto pode e sabe como pode. E quando estamos dizendo que esta universidade, a USP e todas as demais, devem ser a cara do Brasil, é porque essa universidade radicalmente branca, 
na qual se pratica uma cota de $99 \%$ de brancos, não representa o Brasil. Isso é ruim para a universidade, porque ela não reflete a universalidade. A universidade brasileira que queremos não será branca apenas; será branca, indígena, negra, enfim, será a expressão de um Brasil pluriétnico, como de fato é o país. Esse é o Brasil que nós queremos e é por isso que nós defendemos as ações afirmativas e as cotas.

\section{Identidades ${ }^{2}$}

Frei David: Sobre a pergunta por que eu separei nos slides entre "pardo e pretos", esclareço que depois de muitas discussōes com o IBGE para que o mesmo revisse as terminologias usadas na classificação étnica, este demonstrou certa irredutibilidade. Neste sentido, o máximo que a comunidade negra conseguiu foi um acordo: a partir daquele dia, o IBGE utilizaria sempre a terminologia tradicional, pardo e preto, mas que, ao lado, colocaria sempre a terminologia negro, somando os índices daquelas duas. Assim, é possível trabalhar com dados comparativos, mantendo a terminologia do IBGE, até que ele um dia a reveja e a mude.

Yvonne Maggie: Já ouvi várias vezes a expressão "comunidade negra" nesse debate e eu não sei de que negro estão falando, de que comunidade estão falando. Em nome de quem o Frei David propóe que as categorias preto e pardo sejam tomadas como uma categoria única, uma identidade negra? Quem, no Brasil, delegou a alguma liderança de movimento, e o Frei David é uma liderança importantíssima no Brasil, o direito imputar, de criar uma identidade para os outros? Além de tudo, como nós

2. Originalmente, essa parte do debate foi destinada às perguntas dos espectadores. Resolvemos dividir em tópicos temáticos, devido ao limite de espaço destinado à publicação deste debate. vamos criar uma sociedade que se orgulha de alguma etnia? Se orgulhar de quê? Não, não acho que esse seja o caminho do combate ao racismo. O combate ao racismo só pode ser feito quando as pessoas descobriram que elas não são nem homens, nem mulheres, nem brancos, nem negros: são indivíduos e universais. Essa opção proposta por Frei David de unir estatisticamente pretos e pardos através da categoria identitária negro é uma estratégia perigosa e enganadora. Ao fazer a conta de quantos negros (a soma de pretos e pardos) existem no país, contamos os pardos e as misturas de toda a sorte, mas quando implantamos as cotas estamos visando os que se autodefinem como pretos. Só isso explica, por exemplo, as regras implantadas na UnB que privilegia os mais escuros, mas faz a conta do percentual a ser privilegiado com o direito utilizando o número de pretos e pardos. Isso não só é enganoso, como cria uma identidade a muque, que acabará se impondo por força de lei.

José Carlos Miranda: O que é ser negro? Eu posso falar várias coisas aqui: negro é descendente de escravo, tem traços africanos, negros são matizes diferentes da religiāo católica, negro é pobre, mora na favela, é sambista. Em qual a gente se encaixa? E o povo brasileiro é a expressão racial da luta de classes que se expressa numa nação, em um povo, numa cultura, numa história e podemos dizer numa classe social, na classe trabalhadora, no povo trabalhador desse país.

Dojival Vieira: No Brasil, em todos os partidos, da direita, extrema direita à extrema esquerda, a questão racial é marginal, é secundária. Os liberais consideram a nós negros como elementos do folclore, tipos exóticos, que servem para enfeitar as festas. A extrema esquerda tem essa visão marxista, defasada, que o Miranda traz aqui ao debate. O marxismo, 
Miranda, foi incapaz de dar conta da questão racial, porque Marx tinha uma visão etnocêntrica do mundo, pois via o mundo e a África a partir da Europa, portanto, sob a ótica do colonizador. A esquerda não resolveu esse problema jamais. Não resolveu na luta pelo poder, nem enquanto estava no poder. Querem um exemplo? O racismo em Cuba foi, e em certa medida continua sendo, um problema seríssimo para a Revolução, e não me consta que lá o modo de produçáo seja capitalista. O modo de produção em Cuba é socialista e, no entanto, o racismo persiste.

\section{Desigualdades}

Dojival Vieira: $O$ Brasil não será uma democracia enquanto o povo negro, que corresponde a mais da metade da populaçáo, continuar ganhando menos da metade do salário do branco. Considero que a luta por igualdade racial no Brasil é indissociável da luta por democracia, justiça e cidadania, e isso significa a defesa intransigente de que o povo negro que, repito, corresponde a metade do país, deve estar presente em todos os espaços! Náo queremos ações afirmativas só na universidade, só na USP. Queremos no mercado de trabalho, na mídia, em toda parte. Tenho o direito de ser cidadão inteiro! E não pela metade! Acho que a realidade brasileira assusta alguns setores da intelectualidade, alguns setores da esquerda, dessa esquerda que não tem uma visão abrangente da questão e continua a ver a questáo racial como uma questão marginal, como uma questão secundária!

Frei David: Essa briga sobre as cotas é muito, muito, muito interessante! É uma briga por poder. É uma briga econômica. Na UERJ, dos 230 mandados de segurança contra as cotas, $100 \%$ foi de jovens disputando vagas em cursos caros, medicina, odontologia etc. Nenhum processo foi de jovem branco, querendo entrar em pedagogia, letras etc., cursos com pouco investimento por parte do Estado. $\mathrm{Ou}$ seja, é uma briga econômica, por poder. Nós, negros, também queremos poder. Queremos que a economia esteja a nosso favor. Queremos que o Estado beneficie-nos também, com vagas gratuitas nas universidades públicas. Quando um jovem de classe média ganha uma vaga em medicina, são $\mathrm{R} \$ 3.800,00$ por mês que o Estado investiu nele. Deixa de investir em nós negros e pobres sem dinheiro.

José Carlos Miranda: É óbvio que o racismo existe e que o negro ganha menos. Sou um militante e dediquei boa parte da minha vida com outros que acreditam que todos os seres humanos são iguais e que precisamos de uma sociedade que reflita isso. Por isso, que eu luto contra o racismo. Por isso acho que o racismo é um problema de todos aqueles que querem uma sociedade justa, igualitária. Portanto é um problema de todo povo e essas políticas racialistas não se orientam no sentido de uma sociedade igualitária, ela vai acabar nos dividindo (o povo trabalhador) em guetos como nos EUA.

\section{Cidadania}

Yvonne Maggie: Eu penso que tenho uma função como professora, como antropóloga, e como cidadã de falar o que eu penso e é por isso que eu tenho me manifestado. A minha geração é uma geração que lutou por direitos individuais. Não quero ser definida, primeiro, como mulher, mas como intelectual. Quero uma identidade cosmopolita internacional. Quero ser um indivíduo. Talvez, por isso, me espante tanto essa busca por enquadrar as pessoas em uma determinada categoria. Aprendemos a desconstruir isso e a ver que essas identidades são 
construídas. Quando a gente assume individualmente uma identidade "eu sou um negro", você tem toda a responsabilidade em relação àquilo. É uma escolha de foro íntimo. Mas quando o Estado obriga legalmente o cidadáo a ser negro, as coisas começam a mudar de figura. Quando o Estado pergunta "quantos negros são operários?”, ele não está distribuindo direitos de acordo com a categoria negro: ele está apenas descrevendo o lugar de pessoas que se autodefinem assim para saber onde eles estâo. Desconstruir categorias socialmente estabelecidas é uma das tarefas da antropologia e do cidadão cosmopolita. Construir políticas públicas com base em categorias raciais socialmente construídas fará surgir uma nação cheia de orgulhos étnicos. E eu pergunto pra quê? O que faz com que se acredite que ter orgulho étnico é bom? Veja como isso tem levado a dor e a sofrimento pelo mundo afora. Quero me orgulhar de ser um indivíduo, de estar na vida, seja na USP, em uma favela ou em um gabinete. Quero ser uma pessoa cosmopolita e, como diz Anthony Appiah, estar no mundo podendo fazer opçóes.

José Carlos Miranda: $O$ povo brasileiro é a expressão nacional da luta de classes que se expressa em uma nação em um povo, em uma cultura, em uma história. O Estatuto da Igualdade Racial é a lei que quer que cada um fale o que ele é, e a partir do momento em que valida isso, vai haver direitos diferentes de uns e outros cidadáos. Nós, descendentes de escravos, sambista, pobres, da favela, seja qualquer denominação que quiser, não somos nem mais nem menos que qualquer outro, que meus irmãos de classe que estão aqui. Então, nós propomos medidas que se orientam para igualdade das pessoas, melhorar a qualidade da escola pública da periferia para igualar com as escolas privadas. Mudar a política econômica vai ajudar os pobres a terem condiçóes e meios materiais de estar na USP, na UNICAMP.
Dojival Vieira: Outra coisa fundamental a se colocar aqui: não é verdade que o Estado brasileiro ou o Estatuto da Igualdade Racial vá obrigar a quem quer que seja a assumir uma cor. Vocês podem pegar o Estatuto da Igualdade Racial e verão sobre introdução do quesito cor como autoclassificação, no artigo 17. Não é verdade que o Estado estaria entrando nisso. O Estado já entrou nisso, professora Maggie, na Constituição que a senhora mencionou de 1890 , através do decreto de no 528 , de 28 de julho de 1890, que tinha por objetivo regularizar o serviço de introdução e localização dos imigrantes do Brasil. O decreto de 28 de julho de 1890 diz no, artigo primeiro, que é inteiramente livre a entrada nos portos da República dos indivíduos válidos e aptos para o trabalho, que não se acharem sujeitos à ação criminal de seu país, com exceção dos indígenas da Ásia e da África, que somente mediante autorização do Congresso Nacional poderão ser admitidos de acordo com as condições que forem estipuladas. Isso é a-racial?

Frei David: A USP, para diminuir a pressão da comunidade negra, criou o programa do INCLUSP, que vocês, com certeza, estáo acompanhando. Por que o INCLUSP não contemplou as várias propostas que a comunidade negra apresentou nos últimos quatro anos? $\mathrm{O}$ INCLUSP, na verdade, atende aos interesses daqueles que dirigem a USP com visão da elite. Vimos que os dirigentes da USP náo permitiriam avançar nos pontos que acreditávamos serem mais eficientes. Nós reivindicamos da reitora atual que, pelo menos, colocasse um corte socioeconômico na exigência para um aluno se beneficiar da pontuação oferecida pelo INCLUSP. Com o corte socioeconômico, evitar-se-ia mascarar a realidade. Ou seja, alunos que ganhem até um salário mínimo por renda per capita poderiam participar do programa. A USP não aceitou nossa proposta, revelando 
250| Debate

que, na verdade, não queria fazer um trabalho forte de inclusão de pobres e negros.

\section{Consideraçóes Finais}

José Carlos Miranda: As cotas são um funil, Frei David tem razão: só os melhores entre os pobres passarão, só os que tiverem escola melhor, que tiverem condiçôes melhores. Porque o vestibular é a cota e o vestibular é desde que nasce; quem tem alimentação boa; quem tem educação boa; o vestibular é de classe. Então os pobres continuarão a não ter acesso à universidade pública, e nada será resolvido, há não ser a criação de uma pequena elite como nos EUA e a maioria do povo pobre continuará na mesma. Todo estudante que termina o segundo grau tem direito a vagas na universidade se ele quiser, ponto. Nós temos que dar é a condição para que todos sejam iguais. Por isso, eu falo sempre contra cotas raciais, porque isso é um perigo enorme. Cotas raciais? Não vai resolver o problema, porque cotas sociais não vão resolver o problema da falta de investimento maciço nos serviços públicos. É preciso melhorar $\mathrm{e}$ aumentar radicalmente as vagas, é preciso mais professores, e é uma falácia dizer que as cotas resolverão isso. É preciso acabar com a DRU (Desvio de Receita da União) que retira verbas da educação, é preciso melhorar os salários dos profissionais de educação. Na verdade, precisamos mudar a política econômica, este é o verdadeiro nó da questão e isso é o que as chamadas políticas de ação afirmativa escondem! Precisamos de medidas que vão em direção a resolução dos problemas. Essas ONG's do Frei Davi, do Dojival só querem as migalhas e as esmolas e não lutar para realmente transformar a situação do povo negro e pobre deste país.

Yvonne Maggie: $\mathrm{O}$ combate ao racismo feito a partir de políticas com base na "raça" implica num paradoxo. Combater o racismo deve começar sempre pela negação da idéia de raça e não pela constituição dessa categoria nefasta. Por que criar a idéia de "raça" legalmente para combater o racismo? Quando eu comecei a falar aqui nessa mesa disse que havia alguma coisa em comum entre nós e disse que era a vontade e o desejo de transformar nossa sociedade numa sociedade mais igualitária e menos racista. Eu proponho outra coisa. Eu proponho que não se funda no Brasil uma palavra, uma palavra da antropologia do século XIX que tanto mal fez às sociedades humanas. A idéia de "raça" implica na noção de uma herança moral própria a cada biologia, a cada fenótipo, digamos assim. Esse é um caminho sem volta. O caminho, não é esse, o caminho é a gente inventar uma sociedade que negue a "raça". Uma sociedade que negue que as diferenças fenotípicas sejam carregadas de diferenças morais. Esse é o único caminho e é o caminho que os países que sofreram com o racismo estáo tendo que trilhar. Então, o que venho dizendo desde o início, desde pelo menos 2001 quando tudo isso começou, é que eu acho que essa luta das cotas não tem como objetivo resolver a questáo da eqüidade na universidade pública. Houve uma opção no Brasil e essa opção é política. A política de cotas não tem como objetivo criar justiça e eqüidade para o ensino superior. Essa política de cotas tem como objetivo, político e ideológico, criar uma divisão na sociedade e uma consciência (uma chamada consciência) de que existe o racismo no Brasil. Para enfrentar o racismo propóe-se um caminho sem volta que é reforçar a idéia de "raça". E, para isso, o caminho é o Estado definir e dizer quem é negro e quem não é. E, nesse caminho, o Estado vai se meter obrigando o cidadáo a se definir legalmente como branco ou como negro. Concluindo, mais uma vez eu digo: a opção por ser negro, a opção de se definir por esta 
ou aquela identidade étnica é uma opção individual, é uma opção de foro íntimo na qual o Estado não pode se imiscuir sob pena de criar mais desigualdade, mais racismo e mais violência.

Frei David: Eu quero deixar bem evidenciado aqui: eu acredito na pluralidade, na diversidade como riqueza. Se alguém acha que o Brasil ideal é o Brasil dos valores eurocêntricos, não contem comigo. Lutarei contra essa visão até o fim. Ponto dois: o nosso objetivo é provocar mudanças. Nunca, nos últimos três anos, o Brasil discutiu tanto a questão da exclusão dos negros como agora, quando a questão das cotas foi firmada como debate. Então, nosso objetivo é provocar um debate sobre a pluralidade étnica. Cada etnia tem uma missão a cumprir na sociedade. Basta desta imposição de que todos nós, negros, temos que nos contentar em negar os nossos valores e ficarmos com uma ideologia branca. A vivência plural ideológica dos valores das etnias é uma grande riqueza, é dom de Deus.
Dojival Vieira: Eu começo por dizer que tanto a professora Yvonne Maggie quanto o senhor José Carlos Miranda admitem a existência do racismo apenas verbalmente. Vocês devem ter percebido isso quando se propóe o que fazer? O que botar no lugar? Como é que nós vamos desconstruir e botar abaixo o sistema racista que se estruturou no país e que hoje permeia as relações sociais, econômicas, políticas e está presente em toda parte. O que fazer? A segunda questáo é que a nossa causa tem que ter absoluta independência e autonomia em relação a partidos e a governos. A nossa interlocução não é com governos nem com partidos, é com o Estado brasileiro que nos deve. Terminando, o que nós advogamos é a aprovação do Estatuto da Igualdade Racial, a introdução de cotas e de açôes afirmativas. Felizmente, cerca de 46 universidades brasileiras já adotaram cotas, porque a sociedade caminha sempre na frente do Estado e enfrenta essas resistências e esses preconceitos. Sem tal postura, esse país jamais será um país verdadeiramente democrático e com oportunidades iguais para todos. Muito obrigado. 